Samadov T., Novruzova 5.

\title{
CHOICE OF OPTIMAL TECHNOLOGICAL OPERATION MODE OF OFF-SHORE GAS- CONDENSATE WELLS EXPLOITED IN COMPLICATED CONDITIONS
}

Об’єктом дослідження є новий метод підходу управління оптимальним технологічним режимом роботи газових і газоконденсатних свердловин. Відзначено, що з метою оптимізації технологічного режиму свердловини, шляхом вилучення рідких і твердих частинок, необхідно знати мінімальне значення видобутку газу або швидкості потоку газу, який, в свою чергу, забезпечується визначенням відповідного значення забійного тиску. Для визначення забійного тиску, при якому свердловина виходить на оптимальний режим роботи, було отримано рівняння, що має складну будову щодо забійного тиску (тиску в черевику підйомника), для вирішення якого застосовувався графоаналітичний метод. Пропонований спосіб оптимізації роботи газових і газоконденсатних свердловин був апробований на основі фактичних даних. Також була показана можливість визначення оптимального режиму роботи газових і газоконденсатних свердловин за допомогою визначення значень забійного тиску, при яких забезпечується винесення рідких і твердих частинок із забою свердловин на земну поверхню. При цьому використовувалися вихідні дані для свердловин (№ 652 і 704), які експлуатуються на VII горизонті родовища Сангачал-море-Дування-море-Хара-Зиря (Азербайджан), для визначення їх технологічних режимів. Показано, що представляється можливим підвищити продуктивність морських газових і газоконденсатних свердловин шляхом зміни конструкцї̈ ї підйомників. Запропонований спосіб дозволяє витягувати рідкі і тверді частинки зі стовбура на земну поверхню. Для кожного випадку розраховувалися швидкості осадження частинок в газовому середовищі і швидкість потоку газу в черевику підйомника. Судячи за значенням різниці швидкостей осадження частинок, що визначалися, $i$ потоку газу в черевику підйомника, встановлюється можливість утворення рідких пробок в стовбурі свердловин. У випадку встановлення виникнення ситуацї, коли швидкість газового потоку не забезпечить витяг рідких частинок на земну поверхню, пропонується змінити діаметри підйомних труб.

Ключові слова: експлуатаційна свердловина, оптимальний технологічний режим, видобуток газу $і$ конденсату, газові та газоконденсатні родовища.

Received date: 10.06.2019

Accepted date: 27.06 .2019

Published date: 30.08 .2019
Copyright (C) 2019, Samadov T., Novruzova S. This is an open access article under the CC BY license (http://creativecommons.org/licenses/by/4.0)

\section{Introduction}

As it is known, one of the key issues in the development of a project for the development of gas and gas condensate fields is the choice of technological modes of operation of wells. Maintaining stable gas and condensate production from fields at the development stages can be provided by the selected technological regimes for wells [1, 2]. However, due to obstacles encountered in the process of gas production, the well operation mode is violated, and gas production decreases [2, 3].

The development of new methods and approaches to determine and control the optimal technological modes of operation in wells to increase or stably maintain well production at the stages of field development are important issues for gas production processes [2, 4]. In connection with a change in the design of the hoists in order to stably maintain or increase the productivity of gas and gas condensate wells, it is necessary to ensure the selection of new technological operating modes $[2,5]$. So, in the study [3] it is shown that it is impossible to develop unified methods to combat sand ingress in the well for the conditions of all fields. The difference in the geological and physical properties of the productive formations of many fields, well operating conditions, production equipment and other factors require special studies to select the most effective sand ingress control methods.

In [5], a method is proposed for removing liquid from a gas condensate well and an installation for its implementation.

In [6], the causes of the destruction of the productive reservoir and the main methods of dealing with the removal of mechanical impurities from the well are considered. Depending on the destruction of the reservoir, various formulations with improved properties are recommended for use during the repair work.

The study [7] provides an overview of the work to prevent sand formation in waterlogged gas wells, where it is emphasized that the appearance of sand in the bottom of gas and gas condensate wells is due to various reasons, mainly related to the mechanical properties of the reservoir. Therefore, the main problem facing researchers 
is the development of new technologies and process fluids that would prevent the destruction of the near-well zone of the formation by fixing and cleansing the formation of reaction products. And also reduce the likelihood of recontamination of the near-well zone, increase the efficiency and reliability of the work, reduce their duration and cost, ensure minimum costs for the subsequent development of the well being repaired due to a smoother start-up of the well.

In the publication [8], the basics of constructing an automated system designed to record the removal of mechanical impurities (sand) from gas production wells are considered.

The results of some studies show that at a later stage of production, the minimum energy required to draw fluids from the well is higher than at the initial stage of production $[9,10]$.

It should be noted that in most of the works devoted to combating the complications associated with the manifestation of liquid and solid particles in the bottom of gas and gas condensate wells, the tasks of determining technological measures in the bottomhole zone of the wells are studied.

An analysis of the relevant work confirms the relevance of the study of tasks to optimize the operation of wells under complicated conditions associated with the manifestation of liquid and solid particles in the well. Therefore, from the point of view of the nature of the research, it is required to determine the minimum bottomhole pressure at which the well will operate in the indicated optimal mode for a certain time.

In view of the foregoing, the object of research is a new method for optimal control of the technological regime of gas and gas condensate wells. And the aim of research is its practical justification, taking into account the manifestation of complications directly in their nearwell conditions.

\section{Methods of research}

The new approach method mentioned in the previous section was applied to determine the technological operating modes of wells (No. 652 and 704) operated on the VII horizon of the Sangachal-Sea-Duvanny-Sea-Khara-Zira field (Azerbaijan). The sequence of calculations of the methodology, the results obtained and their comparison with field data are given below.

The extraction of liquid and solid particles from the near-well zone of the wells mainly depends on the rate of gas rise in the bore or production of the well, as well as on the physical properties of the gas, liquid and solid particles, well design and other parameters.

Since the extraction of liquid and solid particles on the earth's surface from the bottom of a gas condensate well is ensured at a minimum gas flow rate in the elevator shoe or at a minimum well production, the source data should be known from production wells.

Below are the production data required for the wells.

Initial information for well No. 652:

- reservoir pressure $P_{p l}=17.5 \mathrm{MPa}$;

- reservoir temperature $T_{p l}=365 \mathrm{~K}$;

- coefficients of hydraulic resistance of filtration -

$A=42 \cdot 10^{-2} \mathrm{MPa} \cdot$ day/thousand $\cdot \mathrm{m}^{3}$;

$B=65 \cdot 10^{-5}\left(\mathrm{MPa} \cdot \text { day } / \text { thousand } \cdot \mathrm{m}^{3}\right)^{2}$;
- elevator design:

I row: 4" - $2766 \mathrm{~m} ; 2.5^{\prime \prime}-750 \mathrm{~m}$;

II row: $2.5^{\prime \prime}-2736 \mathrm{~m}$;

- diameter of the lift of the first row in the shoe $d=$ $=2.5^{\prime \prime}=0.0625 \mathrm{~m}$;

- gas compressibility coefficient in $P_{p l}$ and $T_{p l}, Z=0.9$;

- well flow rates $-Q_{g}=90 \cdot 10^{3} \mathrm{~m}^{3} /$ day; $Q_{k}=1.5 \mathrm{t} /$ day;

$Q_{v}=5 \mathrm{~m}^{3} /$ day;

- well productivity coefficient -

$K=1.2$ thousand $\cdot \mathrm{m}^{3} / \mathrm{MPa} \cdot$ day .

Initial information for well No. 704:

- reservoir pressure $P_{p l}=17.5 \mathrm{MPa}$;

- reservoir temperature $T_{p l}=365 \mathrm{~K}$;

- coefficients of hydraulic resistance of filtration -

$A=48 \cdot 10^{-2} \mathrm{MPa} \cdot$ day $/$ thousand $\cdot \mathrm{m}^{3}$;

$B=50 \cdot 10^{-5}\left(\mathrm{MPa} \cdot \mathrm{day} / \text { thousand } \cdot \mathrm{m}^{3}\right)^{2}$;

- elevator design:

I row: 4" $-2902 \mathrm{~m} ; 2.5^{\prime \prime}-620 \mathrm{~m}$;

II row: $2.5^{\prime \prime}-2863 \mathrm{~m}$;

- diameter of the lift of the first row in the shoe $d=$ $=2.5^{\prime \prime}=0.0625 \mathrm{~m}$;

- gas compressibility coefficient in $P_{p l}$ and $T_{p l}, Z=0.9$;

- well flow rates $Q_{g}=110 \cdot 10^{3} \mathrm{~m}^{3} /$ day; $Q_{k}=12 \mathrm{t} /$ day;

$Q_{i}=8 \mathrm{t} /$ day;

- well productivity coefficient:

$K=1.6$ thousand $\cdot \mathrm{m}^{3} / \mathrm{MPa} \cdot$ day .

The minimum gas production to ensure the extraction of liquid and solid particles from a gas condensate well is determined by the following equation:

$$
q_{\min }=\frac{\pi d^{2}}{4} v_{o} \frac{T_{0} P_{b}}{T_{p l} P_{0} Z},
$$

where $v_{o}$ - the sedimentation rate of particles in a gaseous medium:

$$
v_{o}=10\left(45-0.045 P_{b}\right)^{\frac{1}{4}} P_{b}^{\frac{1}{2}},
$$

where $T_{0}$ and $P_{0}$ - the temperature and pressure in the normal condition, respectively; $P_{b}$ - bottomhole pressure.

Then, given (2) in (1) to calculate the minimum gas production, let's obtain:

$$
q_{\min }=0.785 \cdot 0.0625^{2} \cdot 10\left(45-0.045 P_{b}\right)^{\frac{1}{4}} P_{b}^{\frac{1}{2}} \cdot \frac{T_{0} P_{b}}{T_{p l} P_{0} Z},
$$

so

$$
q_{\min }=25.3\left(45-0.045 P_{b}\right)^{\frac{1}{4}} P_{b}^{\frac{1}{2}} .
$$

If to take into account the expression obtained in the inflow equation $\left(P_{p l}^{2}-P_{b}^{2}=A Q_{g}+B Q_{g}^{2}\right)$, then let's obtain the equation for determining the bottomhole pressure. 


\section{Research results and discussion}

Let's carry out calculations for well No. 652.

The minimum value of gas production or gas flow rate to ensure the extraction of liquid and solid particles from the well corresponds to the bottomhole pressure determined by the equation:

$$
\begin{aligned}
& 17.5^{2}-P_{b}^{2}=42 \cdot 10^{-2} \cdot 25.3\left(45-0.045 P_{b}\right)^{\frac{1}{4}} P_{b}^{\frac{1}{2}}+ \\
& +65 \cdot 10^{-5}\left[25.3\left(45-0.045 P_{b}\right)^{\frac{1}{4}} P_{b}^{\frac{1}{2}}\right]^{2} .
\end{aligned}
$$

Regarding $P_{b}$ equation (5) is solved by two methods:

1) iterative method;

2) graphoanalytical method.

To determine the bottomhole pressure $P_{b}$, let's select the graphoanalytical method.

The left and right sides of the resulting equation are denoted by $y$ :

$$
\begin{aligned}
& y=f\left(P_{b}\right) \text { and } y=\varphi\left(P_{b}\right), \\
& y=17.5^{2}-P_{b}^{2}, \\
& y=10.5\left(45-0.045 P_{b}\right)^{\frac{1}{4}} P_{b}^{\frac{1}{2}}+0.41\left[\left(45-0.045 P_{b}\right)^{\frac{1}{4}} P_{b}^{\frac{1}{2}}\right]^{2} .
\end{aligned}
$$

The solution of the system of equations (6) using the graphoanalytical method becomes possible at given bottomhole pressure values $\left(P_{b}=16,15,14,13,12,11 \mathrm{MPa}\right)$.

Based on these values, graphs $y=f\left(P_{b}\right)$ and $y=\varphi\left(P_{b}\right)$ are constructed, and the point of their intersection is considered the value of the bottomhole pressure. The determined bottomhole pressure provides the extraction of liquid or solid particles from the bottom to the earth's surface.

First, let's calculate the values $y$ according to $y=f\left(P_{b}\right)$ :

$$
\begin{aligned}
& y(16)=17.5^{2}-16^{2}=306.25-225=50.25, \\
& y(15)=306.25-225=81.25, \\
& y(14)=306.25-196=110.25, \\
& y(13)=306.25-169=137.25, \\
& y(12)=306.25-144=162.25, \\
& y(11)=306.25-121=185.25 .
\end{aligned}
$$

The sequence and calculation results of the right side of the equation $y=\varphi\left(P_{b}\right)$ are given in Table 1 .

First, it is determined $y=f\left(P_{b}\right)$ (dependence (1)), $y=\varphi\left(P_{b}\right)$ (dependence (2)), and then $P_{b}=13.1 \mathrm{MPa}$ is determined in accordance with dependences (1) and (2) (Fig. 1).

With this value of the bottomhole pressure, the removal of liquid and solid particles to the earth's surface is possible. According to this bottomhole pressure value, the minimum well production is determined:

$$
q_{\min }=K\left(P_{p l}^{2}-P_{b}^{2}\right)^{n} .
$$

It is believed that $n=1$ :

$$
q_{\min }=1 \cdot 2\left(17.5^{2}-13 \cdot 1^{2}\right)=161.6,
$$

so

$$
q_{\min }=161.6 \cdot 10^{3} \mathrm{~m}^{3} / \text { day } .
$$

Actual production of well No. 652 is $10^{2} \cdot 10^{3} \mathrm{~m}^{3} /$ day, that is $Q_{f}<q_{\min }$, the production of the analyzed well is less than the determined theoretical production. In this case, it is impossible to extract liquid and solid particles to the earth's surface in the analyzed well. In other words, well production is reduced due to the formation of liquid plugs in the bottomhole zone of well No. 652 .

To eliminate the fluid plug formed in the bottomhole zone of production wells in offshore conditions, the well is purged with gas.

At the same time, the well is operated without a fitting with minimal buffer pressure and maximum production. Then the product from the well is sent to the flow line.

When purging, the well is operated by «free production», which is determined by the following equation:

$$
\begin{aligned}
& q_{S}=\frac{\sqrt{A^{2}+4(B+\theta)\left(P_{p l}^{2}-\theta^{2 S}\right)}-A}{2(B+\theta)}, \\
& \theta=1.377 \lambda \frac{Z_{a v}^{2} T_{a v}^{2}}{d_{v}^{5}}\left(e^{2 S}-1\right), \\
& s=0.0683 \frac{\bar{\rho} H}{Z_{a v} T_{a v}},
\end{aligned}
$$

where $\lambda$ - the hydraulic resistance coefficient of the lift; $Z_{a v}$ - the average coefficient of gas compressibility in the well; $T_{a v}$ - the average temperature of gas in the well; $d_{i}-$ the internal diameter of the lift.

The sequence and results of the calculation of the equation for well No. 652

\begin{tabular}{|c|c|c|c|c|c|c|c|c|c|}
\hline No. & $P_{b}$ & $0.045 \cdot P_{b}$ & $45-[3]$ & $\sqrt[4]{[4]}$ & $\sqrt{P_{b}}$ & $10.4 \cdot[5] \cdot[6]$ & $\sqrt{[4]}$ & $0.41 \cdot[8] \cdot P_{b}$ & $y=[7]+[9]$ \\
\hline 1 & 16 & 0.728 & 44.27 & 2.579 & 4.0 & 109.35 & 6.654 & 43.65 & 153 \\
\hline 2 & 15 & 0.6825 & 44.32 & 2.580 & 3.87 & 105.84 & 6.657 & 40.94 & 146.78 \\
\hline 3 & 14 & 0.6370 & 44.36 & 2.581 & 3.74 & 102.32 & 6.660 & 38.23 & 140.55 \\
\hline 4 & 13 & 0.5915 & 44.41 & 2.581 & 3.61 & 98.76 & 6.664 & 35.32 & 134.28 \\
\hline 5 & 12 & 0.5460 & 44.45 & 2.582 & 3.46 & 94.70 & 6.667 & 32.80 & 127.5 \\
\hline 6 & 11 & 0.5005 & 44.50 & 2.583 & 3.32 & 90.90 & 6.671 & 30.08 & 120.98 \\
\hline
\end{tabular}




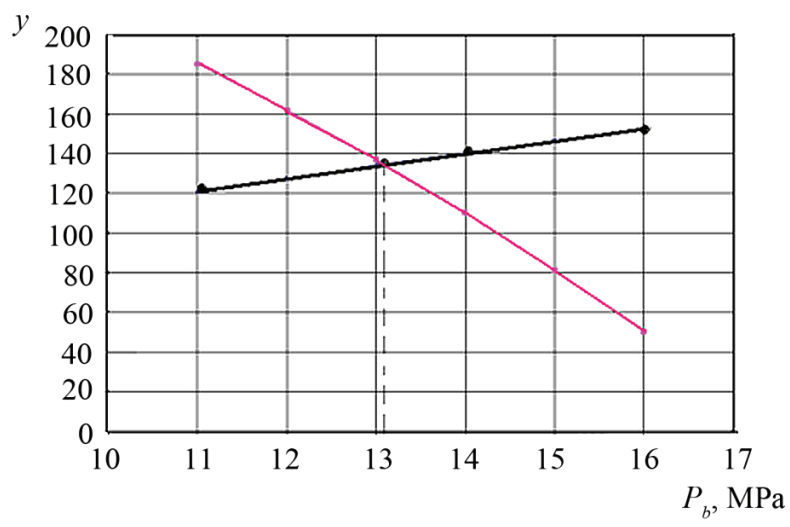

Fig. 1. Determination by graphoanalytical method for well No. 652

It should be noted that the equation used is applied when the gas flow velocity at the mouth does not exceed the critical velocity $(400 \mathrm{~m} / \mathrm{s})$.

Let's assume that when a gas is purged with a bottomhole zone, well production is twice its actual value. In this case, the production of the well will be $\mathrm{m}^{3} /$ day.

In most cases, gas is purged with the bottomhole zone of the well within $(15 \div 30)$ minutes.

In this case, gas loss during the purge process will be:

$$
q_{o}=\frac{204000}{24 \cdot 60}(15 \div 30)=(2125 \div 4250) \mathrm{m}^{3},
$$

SO

$$
\bar{q}_{o}=3100 \mathrm{~m}^{3} .
$$

On the other hand, it should be borne in mind that gas purging of the bottomhole zone of the well is carried out 3 or 4 times during the month, and $\bar{q}_{\text {month }}=9300 \mathrm{~m}^{3}$ of gas is consumed during the month.

Gas loss during the year will be:

$$
\bar{q}_{\text {year }}=9300 \cdot 12=111600=111.6 \text { thousand } \mathrm{m}^{3} / \text { year. }
$$

Let's determine the diameter and length of the elevator at which it is possible to extract solid particles from the bottom of the well to the earth's surface.

The calculations are carried out in the following sequence:

- determination of the rate of deposition of particles

in a gaseous medium:

$$
\begin{aligned}
& v_{o}=10\left(45-0.045 P_{b}\right)^{\frac{1}{4}} P_{b}^{\frac{1}{2}}= \\
& =10(45-0.045 \cdot 13.1)^{\frac{1}{4}} \cdot 13.1^{\frac{1}{2}}=9.3 \mathrm{~m} / \mathrm{s}
\end{aligned}
$$

- the amount of gas produced per second:

$$
q_{o}=\frac{102000}{24 \cdot 60 \cdot 60}=1.18 \mathrm{~m}^{3} / \mathrm{s}
$$

- well production at the bottom hole condition per second:

$$
q_{S}=1.18 \frac{0.1}{13.1} \cdot \frac{365 \cdot 0.98}{293}=0.011 \mathrm{~m}^{3} / \mathrm{s}
$$

- gas flow rate in the shoe of the lift:

$$
v_{s}=\frac{0.011}{0.785^{2}-0.0625^{2}}=3.6 \mathrm{~m}^{3} / \mathrm{s} .
$$

From the result obtained, it becomes clear that due to the fact that the diameter of well No. 652 is equal to $2.5^{\prime \prime}$ the gas flow rate will not ensure the extraction of liquid particles to the earth's surface. Therefore, it is necessary to reduce the diameter of the riser pipe. For this purpose, it is necessary to change the design of the elevator, that is, increase the height of the first row of the elevator $150 \mathrm{~m}$ and take the diameter 1.5". In this case, the first row of the well design is taken as follows: $4^{\prime \prime}-2766 \mathrm{~m}, 2.5^{\prime \prime}-750 \mathrm{~m}, 1.5^{\prime \prime}-150 \mathrm{~m}$, and the second row is left as in the previous condition.

For the case $d=1.5^{\prime \prime}$, let's determine the gas flow velocity in the shoe:

$$
v_{s}=\frac{0.011}{0.785^{2}-0.038^{2}}=9.7 \mathrm{~m} / \mathrm{s}
$$

that is, in the design of the proposed well, the gas flow rate in the shoe exceeds the rate of deposition of liquid particles.

Thus, the loss of gas will be prevented, since when changing the length and diameter of the elevator it will be possible to extract liquid or solid particles from the bottom of well No. 652 onto the earth's surface.

According to the developed method, let's carry out the following calculations for well No. 704 .

The minimum value of gas production or gas flow rate to ensure the extraction of liquid and solid particles from the well corresponds to the bottomhole pressure determined by the equation:

$$
\begin{aligned}
& 17.5^{2}-P_{b}^{2}=48 \cdot 10^{-2} \cdot 25.3\left(45-0.045 P_{b}\right)^{\frac{1}{4}} P_{b}^{\frac{1}{2}}+ \\
& +65 \cdot 10^{-5}\left[25.3\left(45-0.045 P_{b}\right)^{\frac{1}{4}} P_{b}^{\frac{1}{2}}\right]^{2}, \\
& 17.5^{2}-P_{b}^{2}=12.1\left(45-0.045 P_{b}\right)^{\frac{1}{4}} P_{b}^{\frac{1}{2}}+ \\
& +0.42\left(45-0.045 P_{b}\right)^{\frac{1}{2}} P_{b} .
\end{aligned}
$$

Dependencies $y=f\left(P_{b}\right)$ and $y=\varphi\left(P_{b}\right)$ are built:

$$
\begin{aligned}
& y=17.5^{2}-P_{b}^{2}, \\
& y=12.1\left(45-0.045 P_{b}\right)^{\frac{1}{4}} P_{b}^{\frac{1}{2}}+0.42\left(45-0.045 P_{b}\right)^{\frac{1}{2}} P_{b} .
\end{aligned}
$$

The values $y=17.5^{2}-P_{b}^{2}$ for the given bottomhole pressures $\left(P_{b}=16,15,14,13,12,11 \mathrm{MPa}\right)$ are calculated for well No. 652 (these results are identical for well No. 704).

The sequence and calculation results of the right side of the equation $y=\varphi\left(P_{b}\right)$ are given in Table 2 .

First, it is determined $y=f\left(P_{b}\right)$ (dependence (1)), $y=\varphi\left(P_{b}\right) \quad$ (dependence $\left.(2)\right)$, and then $P_{b}=12.8 \mathrm{MPa}$ is determined in accordance with dependences (1) and (2) (Fig. 2). 
The sequence and results of the calculation of the equation for well No. 704

\begin{tabular}{|c|c|c|c|c|c|c|c|c|c|}
\hline No. & $P_{b}$ & $0.0455 P_{b}$ & $45-[3]$ & $\sqrt[4]{4}$ & $\sqrt{P_{b}}$ & $12.1 \cdot[5] \cdot[6]$ & $\sqrt{[4]}$ & $0.32 \cdot[8] \cdot[2]$ & $y=[7]+[9]$ \\
\hline 1 & 16 & 0.728 & 44.27 & 2.579 & 4.00 & 124.82 & 6.654 & 34.07 & 158.89 \\
\hline 2 & 15 & 0.6825 & 44.32 & 2.580 & 3.87 & 120.81 & 6.657 & 31.95 & 152.76 \\
\hline 3 & 14 & 0.6370 & 44.36 & 2.581 & 3.74 & 116.80 & 6.660 & 29.84 & 146.64 \\
\hline 4 & 13 & 0.5915 & 44.41 & 2.581 & 3.61 & 112.74 & 6.664 & 27.72 & 140.46 \\
\hline 5 & 12 & 0.5460 & 44.45 & 2.582 & 3.46 & 108.10 & 6.667 & 25.60 & 133.70 \\
\hline 6 & 11 & 0.5005 & 44.50 & 2.583 & 3.32 & 103.76 & 6.671 & 23.48 & 127.24 \\
\hline
\end{tabular}

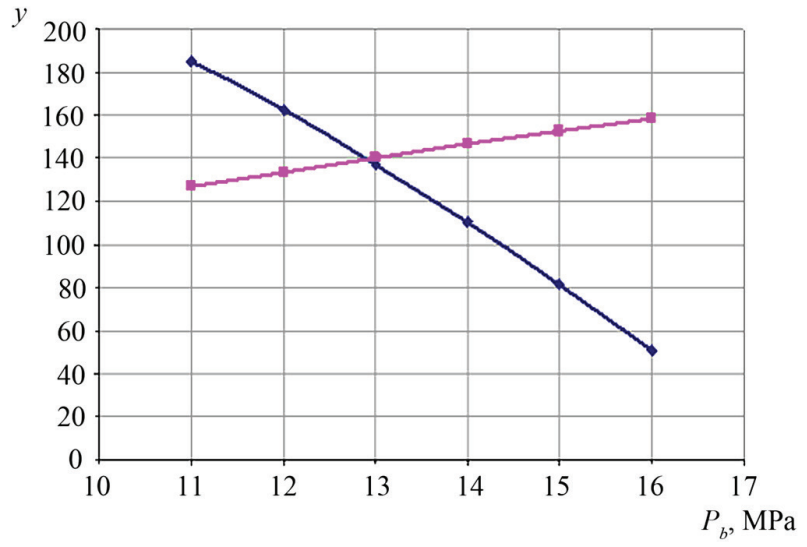

Fig. 2. Determination by graphoanalytical method for well No. 704

According to this bottomhole pressure value, the minimum well production is determined:

$$
\begin{aligned}
& q_{\min }=K\left(P_{p l}^{2}-P_{b}^{2}\right)^{n}= \\
& =1.6\left(17.5^{2}-12.8^{2}\right)=227.7 \text { thousand } \mathrm{m}^{3} / \text { day. }
\end{aligned}
$$

Actual production of well No. $704 Q_{f}<q_{\min }(110<227.7)$ :

$q_{g}=2 \cdot 110=220$ thousand $\mathrm{m}^{3} /$ day,

$$
q_{o}=\frac{220000}{24 \cdot 60}(15 \div 30)=(2300 \div 4600) \mathrm{m}^{3}
$$

$\bar{q}_{o}=34 \cdot 50 \cdot 3=10350 \mathrm{~m}^{3}$,

$$
\bar{q}_{\text {year }}=10350 \cdot 12=124200 \mathrm{~m}^{3} / \text { day }
$$

Now let's determine the diameter and length of the elevator, at which it is possible to extract solid particles from the bottom of the well to the earth's surface.

The calculations are carried out in the following sequence:

- determination of the rate of deposition of particles in a gaseous medium:

$$
\begin{aligned}
& \mathrm{v}_{o}=10\left(45-0.045 P_{b}\right)^{\frac{1}{4}} P_{b}^{\frac{1}{2}}= \\
& =10(45-0.045 \cdot 12.8)^{\frac{1}{4}} \cdot 12.8^{\frac{1}{2}}=9.4 \mathrm{~m} / \mathrm{s} ;
\end{aligned}
$$

- the amount of gas produced per second:

$q_{o}=\frac{110000}{24 \cdot 60 \cdot 60}=1.27 \mathrm{~m}^{3} / \mathrm{s}$;

- well production in the face conditions per second:

$q_{S}=1.27 \frac{0.1}{12.7} \cdot \frac{365 \cdot 0.9}{293}=0.0112 \mathrm{~m}^{3} / \mathrm{s} ;$

- gas flow rate in the shoe of the lift:

$$
v_{s}=\frac{0.0112}{0.785^{2}-0.0625^{2}}=3.65 \mathrm{~m}^{3} / \mathrm{s}
$$

From the obtained results it can be seen that $v_{o}>v_{s}$ $(7.22>3.65)$. This means that a liquid plug forms in the bottom of the well.

To ensure the extraction of liquid particles on the earth's surface, it is necessary to change the design of the elevator. Therefore, it is necessary to reduce the diameter of the riser pipe and increase the height of the first row of the elevator $120 \mathrm{~m}$. In this case, the first row of the well structure is adopted as follows: 4" $-2902 \mathrm{~m}, 2.5^{\prime \prime}$ $620 \mathrm{~m}, 1.5^{\prime \prime}-120 \mathrm{~m}$.

For the case $d=1.5^{\prime \prime}$, let's determine the gas flow velocity in the shoe:

$$
v_{s}=\frac{0.0112}{0.785^{2}-0.038^{2}}=9.88 \mathrm{~m} / \mathrm{s} \approx 10 \mathrm{~m} / \mathrm{s},
$$

that is, in the design of the proposed well, the gas flow rate in the shoe exceeds the rate of deposition of liquid particles.

Thus, the loss of gas will be prevented, since when changing the length and diameter of the elevator it will be possible to extract liquid or solid particles from the bottom of well No. 652 onto the earth's surface.

\section{Conclusions}

The practical justification of a new method of the optimal control approach for the optimal technological regime of the wells in case of complications associated with the manifestation of liquid and solid particles in the face.

The proposed approach allows to determine the minimum bottomhole pressure at which gas and gas condensate 
wells will operate in the optimal mode due to a change in the design of the elevators.

The proposed method allows to extract liquid and solid particles from the bore of gas and gas condensate wells to the earth's surface and, therefore, to ensure the technological efficiency of their operation.

\section{References}

1. Aliyev, Z. S., Somov, B. Ye., Rogachev, S. A. (2001). Obosnovaniye i vybor optimalnoy konstruktsii gorizontalnykh gazovykh skvazhin. Moscow: Tekhnika, 95.

2. Mirzadzhanzade, A. Kh., Kuznetsov, O. L., Basniyev, K. S., Aliyev, Z. S. (2003). Osnovy tekhnologii dobychi gaza. Moscow: Nedra, 880

3. Bondarenko, V. A., Savenok, O. V. (2014). Issledovaniye metodov i tekhnologiy upravleniya oslozhneniyami, obuslovlennykh peskoproyavleniyami. Gornyy informatsionno-analiticheskiy byulleten, 1, 3-27.

4. Nikitin, B. A., Basnivev, K. S., Alivev, Z. S. (1998). Metodika opredeleniya zaboynogo davleniya v gorizon-talnoy gazovoy i gazokondensatnoy skvazhine s uchetom nalichiya v potoke gaza zhidkosti. Moscow: IRTS Gazprom, 33.

5. Burakov, Yu. G., Minko, A. G., Vdovenko, V. L., Ivanov, V. V. et. al. (1998.06.27). Sposob udaleniya zhidkosti iz gazokondensatnoy skvazhiny $i$ ustanovka dlya yego osushchestoleniya. Patent na izobreteniye RU 2114284 C1. Available at: https://yandex.ru/ patents/doc/RU2114284C1_19980627

6. Gasumov, R. A., Kukulinskaya, Ye. Yu. (2016). Tekhnologicheskiye resheniya, napravlennyye na ogranicheniye vynosa plas- tovogo peska iz dobyvayushchikh gazovykh skvazhin. Nauka, innovatsii, tekhnologii, 3, 165-176.

7. Listak, M. V. (2014). Problemy predotvrashcheniya peskoobrazovaniya v obvodnyayushchikhsya gazovykh skvazhinakh. Neft i gaz Zapadnoy Sibiri: materialy Mezhdunarodnoy nauchnotekhnicheskoy konferentsii, posoyashchennoy 50-letiyu Tyumenskogo industrialnogo instituta. Tyumen: TyumGNGU, 12-14.

8. Popov, Ye. V., Savastyuk, S. S., Yezhov, S. A., Karyuk, V. M., Morozov, I. V. (2017). Kontrol vynosa peska iz promyslovoy gazovoy skvazhiny (po rezultatam ispytaniy i promyshlennoy ekspluatatsii). Ekspozitsiya Neft Gaz, 2, 130-132.

9. Fadairo, A., Olugbenga, F., Sylvia, N. C. (2015). A new model for predicting liquid loading in a gas well. Journal of Natural Gas Science and Engineering, 26, 1530-1541. doi: https:// doi.org/10.1016/j.jngse.2014.09.003

10. Ikpeka, P. M., Okolo, M. O. (2018). Title: Li and Turner Modified model for Predicting Liquid Loading in Gas Wells. Journal of Petroleum Exploration and Production Technology, 9 (3), 1971-1993. doi: https://doi.org/10.1007/s13202-018-0585-6

Samadov Tofig, Doctor of Technical Sciences, Professor, Department of Oil and Gas Engineering, Azerbaijan State Oil and Industry University, Baku, Azerbaijan, e-mail: tofiq.samadov1938@mail.ru, ORCID: http://orcid.org/0000-0002-1211-7877

Novruzova Sudaba, PhD, Associate Professor, Department of Oil and Gas Engineering, Azerbaijan State Oil and Industry University, Baku, Azerbaijan, e-mail: sudaba.novruzova@mail.ru, ORCID: http:// orcid.org/0000-0002-2219-3371 